Onkologie 1986;9(suppl. 1):1

\title{
Inhalt, Vol. 9, Supplement 1, 1986
}

\section{Contents}

Impressum 2

I. H. Hartlapp, Bonn

Epirubicin - Ergebnisse beim Mammakarzinom

Hinweise für Autoren 7

Keiling, R., Strasbourg, Armand, P. P., Villejuif,

Hurteloup, P., Besancon, Cappelaere, P., LillelFrankreich

Die französische FAC-vs-FEC-Studie bei fortgeschritte-

nen Mammakarzinomen 8

D. Christmann, Aschaffenburg

Epirubicin in der Kombinations-Chemotherapie des

metastasierten Mammakarzinoms (VEC) und des fortge-

schrittenen Ovarialkarzinoms (PEC) 11

Drings, P.; Bülzebruck, H.; Manke, H. G. und

Schuler, G., Heidelberg, Hruska, D., Gerlingen

EPICO für die Behandlung des kleinzelligen Bronchial-

karzinoms-3. Zwischenanalyse

14

/. A. Wils, RoermondiNiederlande

Epirubicin bei fortgeschrittenen gastrointestinalen

Tumoren 21

Sonderbände 23

Sauer, H.; Mair, W.; Fink, U. undWilmanns, W., München, Ruckle, H. undMjaaland, I., Würzburg

Polychemotherapie fortgeschrittener Weichteilsarkome

mit 4'-Epi-Doxorubicin (4'-Epi-DX) und Cisplatin

(DDP) 24

Sonderbände 28

Imprint 2

1. H. Hartlapp, Bonn

Epirubicin in Metastasized Breast Cancer 3

Instructions for Authors

7

Keiling, R., Strasbourg, Armand, P. P., Villejuif,

Hurteloup, P., Besancon, Cappelaere, P., Lillel France

The French Phase-IП Trial FAC-vs-FEC in Advanced

Breast Cancer 8

D. Christmann, Aschaffenburg 
Epirubicin in the Combination Chemotherapy of Metastatic Breast Cancer (VEC) and the Advanced Ovarian

Cancer (PEC) 11

Drings, P.; Bülzebruck, H.; Manke, H. G. and

Schuler, G., Heidelberg, Hruska, D., Gerlingen

EPICO in the Treatment of Small Cell Lung Cancer -

3rd Interim Analysis 14

I. A. Wils, Roermondl The Netherlands

Epirubicin in Advanced Gastrointestinal (GI) Cancer . . 21

Special Editions

23

Sauer, H.; Mair, W.; Fink, U. and Wilmanns, W.,

München, Ruckle, H. and Mjaaland, I., Würzburg

Polychemotherapy of Advanced Soft Tissue Sarcomas

with 4'-Epi-Doxorubicin (4'-Epi-DX) and Cisplatinum

(DDP) 24

Special Editions

28

Bibliographischer Hinweis: Inhaltsverzeichnisse dieser Zeitschrift erscheinen regelmäßig in

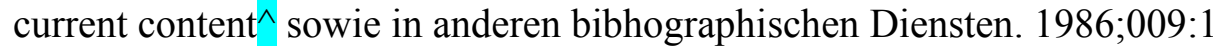

